\title{
АКТУАЛЬНОСТЬ РАЗРАБОТКИ РЕЦЕПТУР И ТЕХНОЛОГИЙ ПРОИЗВОДСТВА РЫБОРАСТИТЕЛЬНЫХ ЧИПСОВ ИЗ НЕТРАДИЦИОННОГО РЫБНОГО СЫРЬЯ
}

\section{Станислав Валерьевич Кузьмин ${ }^{1}$, Владимир Григорьевич Попов ${ }^{2}$, Ирина Васильевна Мозжерина ${ }^{3}$}

\author{
1, 2, 3 Тюменский Индустриальный Университет, Тюмень, Россия \\ ${ }^{1}$ stas45info97@mail.ru, https://orcid.org/0000-0003-1705-9386 \\ 2 popovvg@tyuiu.ru, https://orcid.org/0000-0002-5902-1768 \\ 3 mozzherinaiv@tyuiu.ru, https://orcid.org/0000-0003-1449-8690
}

Аннотация. Данная статья посвящена оценке целесообразности и актуальности разработки рыборастительных чипсов из нетрадиционных видов рыбного сырья с добавлением полифункционального ингредиента на примере изолята белка рапсового жмыха, значительно повышающего белковую составляющую готового продукта с учётом внедрения инновационных технологических процессов.

Продукты с повышенным содержанием белка становятся все более актуальными из-за мировой тенденции, вызванной дефицитом важнейшего нутриента в повседневном рационе питания. По исследованиям проф. Попова В.Г., суточный дефицит белка у взрослого населения Тюменской области составляет 25-30\%, а у подростков - 30-40\% [1].

Рыборастительные чипсы, произведённые на основе рыбы и одновременно обогащенные белковым изолятом рапсового жмыха, способны не только решить проблему обеспечения организма полноценной суточной порцией белка, но и эффрективно перерабатывать вторичное сырьё за счет использования традиционно утилизируемого на предприятиях пищевой промышленности рапсового шрота (жмыха). Если учитывать, что суточные нормы потребления рыбы составляют 60 г/сутки, используя чипсы из рыбы, одновременно решаются две проблемы: удовлетворяется потребность в белке, сокращается его дефицит до 10-15\%, увеличивается потребление рыбопродуктов в 1,5 раза.

Инновационность технологического процесса заключается в способе введения изолята растительного белка в рыбный фарш, способствующего улучшению реологических свойств продукции (гомогенность), повышению влагоудерживающей способности на 8,2士0,4 \% и биодоступности белка на 5,5-8,0 \%. Потенциал производственного процесса нового продукта заключается в значительном количестве местного рыбного сырья (в частности, предлагается использовать рыбу ротан-головешку в целях контроля популяции данного вида), длительном сроке хранения и повышенной белковой ценности.

Ключевые слова: рыбные чипсы, функциональный продукт, белковые ингредиенты, повышенное содержание белка, рапсовый жмых, рыбное сырье.

Для цитирования: Кузьмин, С. В., Попов, В. Г., Мозжерина, И. В. Актуальность разработки рецептур и технологий производства рыборастительных чипсов из нетрадиционного рыбного сырья // Ползуновский вестник. 2021. № 3. С. 163-169. doi: 10.25712/ASTU.2072-8921.2021.03.022.

(c) Кузьмин, С. В., Попов, В. Г., Мозжерина, И. В., 2021 
Original article

\title{
RELEVANCE OF DEVELOPMENT OF FORMULATIONS AND TECHNOLOGIES FOR PRODUCTION OF SNACKS FROM NON-TRADITIONAL FISH RAW MATERIALS
}

\author{
Stanislav V. Kuzmin ${ }^{1}$, Vladimir G. Popov ${ }^{2}$, Irina V. Mozzherina ${ }^{3}$ \\ 1, 2, 3 Tyumen Industrial University, Tyumen, Russia \\ 1 stas45info97@mail.ru, https://orcid.org/0000-0003-1705-9386 \\ 2 popovvg@tyuiu.ru, https://orcid.org/0000-0002-5902-1768 \\ ${ }^{3}$ mozzherinaiv@tyuiu.ru, https://orcid.org/0000-0003-1449-8690
}

Abstract. This review article is devoted to assessing the feasibility and relevance of the development of fish snack and chip products from non-traditional types of fish raw materials with the addition of a multifunctional ingredient, for example, the protein isolate of rapeseed cake, which significantly increases the protein component of the finished product, as well as innovative technological processes and functional ingredients.

High protein foods are becoming more and more relevant due to the global trend caused by the deficiency of an essential nutrient in the daily diet. According to the research of prof. Popova V.G. the daily protein deficiency in the adult population of the Tyumen region is $25-30 \%$, and in adolescents $30-40 \%$.

Fish chips, enriched with protein isolate of rapeseed meal, are able not only to solve the problem of providing the body with a full daily portion of protein, but also to process recyclable materials through the use of rapeseed meal (oilcake) traditionally utilized at food industry enterprises. The daily consumption of fish is $60 \mathrm{~g}$ / day, using fish chips, two problems are simultaneously solved: the need for protein is satisfied, the deficit is reduced to $10-15 \%$, the consumption of fish is increased by 1.5 times.

The innovation of the technological process lies in the method of introducing vegetable protein isolate into minced fish, which improves the rheological properties of the product and the bioavailability of the protein. The potential of the new product lies in a significant amount of fish raw materials for the production of the product (in particular, it is proposed to use Amur sleeper fish in order to control the population of this species), a long shelf life and an increased protein value.

Keywords: fish chips, functional product, protein ingredients, high protein content, rapeseed cake, fish raw materials.

For citation: Kuzmin, S. V., Popov, V. G. \& Mozzherina, I. V. (2021). Relevance of development of formulations and technologies for production of snacks from non-traditional fish raw materials. Polzunovskiy vestnik, (3), 163-169. (In Russ.).doi: 10.25712/ASTU.2072-8921.2021.03.022.

\section{ВВЕДЕНИЕ}

Актуальность научного обзора заключается в получении современных теоретикометодологических знаний для разработки рецептур, технологии и производства рыборастительных чипсов с повышенным содержанием белка путем введения изолята белка, полученного из вторичного растительного сырья. Цель исследования заключается в разработке рецептуры и технологии производства чипсов из рыбы ротан-головешка с улучшенными органолептическими свойствами (вкус, запах), пищевой ценностью, внешним видом, сокращением трудоемкости, энергозатрат на его приготовление, снижение себестоимости на основе проведения патентно- информационного поиска аналогичной продукции.

Задача исследования состоит в поиске рациональной технологии производства чипсов из рыбы, а также выборе способа экстракции белкового изолята из рапсового жмыха с целью создания продукта функционального назначения, с повышенным содержанием белка, низкой себестоимостью и простотой изготовления.

Создание рыборастительных чипсов не является полноценной «инновацией» в качестве пищевого продукта, но в качестве продукта с функциональной направленностью рассматривается крайне редко. В работе представлена потенциальная технология производства проектируемого продукта.

ПОЛЗУНОВСКИЙ ВЕСТНИК № 32021 


\section{ОСНОВНАЯ ЧАСТЬ}

Производство функциональных продуктов питания стремительно развиваются по всему миру и одним из приоритетных сегментов являются продукты питания на основе рыбы морской и пресноводных водоёмов, а также нерыбных продуктов моря.

По данным Института питания РАМН, ежегодный дефицит пищевого белка в России превышает 1 млн тонн. Снижение употребления количества белка полностью совпадает современными мировыми тенденциями снижения обеспеченности населения Земли белком животного происхождения.

Учеными Воронежской государственной технологической академии Антиповой Л.В., Дворяниновой О.П. и Калач Е.В. зарегистрировано изобретение на технологию производства рыбных чипсов на основе прудовой рыбы. Данный способ производства включает разделку сырья на филе и удаление малоценных компонентов с последующим измельчением до тестообразного фарша при помощи куттера. Затем полученную массу обрабатывают при помощи острого пара при температуре $120-130{ }^{\circ} \mathrm{C}$ в течение 15 минут, после чего следует охлаждение до $25-27^{\circ} \mathrm{C}$ с последующим выдерживанием с целью структурирования компонентов, замораживанием и приготовлением во фритюре. Предложенный способ приготовления рыбных чипсов позволяет улучшить органолептические качества продукта, стабилизировать цвет, улучшить внешний вид и консистенцию продукта, а также значительно сократить трудоемкость и снизить энергозатраты на его приготовление, что, в свою очередь, понижает себестоимость продукта [2].

Специалистами Южного научно-исследовательского института морского рыбного хозяйства и океанографии Яковлевой 3.А. и Зубченко Д.Г. предложен способ производства рыбных и мидийных крекеров. Целью данной разработки является улучшение вкусовых качеств и консистенции готового продукта и снижение его себестоимости. Сущность способа заключается в том, что в качестве сырья берут пищевые рыбные отходы, составляющие 30-40 \% к массе, направляемой на разделку рыбы, или мидийный бульон, образующийся при бланшировании мидий при отделении мяса от створок, и бульон, получаемый при варке мяса мидий при изготовлении пресервов [3].

Группа учёных из ФГБНУ "ВНИРО" Артемов Р.В., Артемов А.В., Арнаутов М.В. разработала способ производства рыбных чип- сов из хамсы. Изобретение относится к рыбной промышленности, а именно к производству сухих закусочных продуктов, типа чипсов, снеков, крекеров из рыбы. В результате разработки был получен сухой закусочный продукт длительного срока хранения с ярко выраженным ароматом и вкусом рыбы. Продукт призван расширить ассортимент готовых к употреблению пищевых продуктов данной категории, обладающих улучшенными вкусовыми качествами [4].

Стен Квист, Томми Карльссон, Джон Марк Лотер, Де Кастру Фернанду Басиле разработали метод фракционирования жмыха и измельченного жмыха масличных семян (в том числе рапсового жмыха). Данное изобретение позволяет получить из вторичного сырья четыре различных фрракции: фракцию волокон, протеиновую фрракцию и фракции эмульгированного масла. Данные фракции могут найти применение в различных сферах пищевой промышленности. В частности, протеиновая фрракция может использоваться в качестве белковой добавки для рыбных чипсов [5].

Миневич И.Э., Осипова Л.Л., Зубцов В.А. разработали способ получения белка из жмыха семян льна. Данное изобретение предлагает извлечение из жмыха семян льна белка. Способ позволяет повысить выход белка и качество целевого продукта за счет увеличения в нем содержания протеина. Представленный способ получения белка из жмыха семян льна позволяет получить продукт, содержащий не менее 75 \% льняного белка, характеризующегося полным набором незаменимых для человеческого организма аминокислот. Белковый продукт способен значительно повысить пищевую и биологическую ценность рыбного продукта [6].

Авторами Лобановым В.Г., Минаковой А.Д., Шульвинской И.В., Щербаковым В.Г., Щербиным В.В. был разработан способ получения структурно модифицированного рапсового белкового продукта. Изобретение относится к получению модифицированных белковых продуктов. Главной особенностью изобретения является получение биомодифрцированного белкового продукта высокой биологической ценности с улучшенными функциональными свойствами: жироудерживающей, пенообразующей и жироэмульгирующей способностями из шрота частично гидролизованных семян рапса. Результат, полученный в ходе данной разработки, используют в качестве основного способа при производстве обогащенных белком рыбных чипсов [7]. 
Эльдарханова И.Б. и Эльдарханов Р.А. разработали упаковку для сушеных пищевых продуктов, в частности, изобретение можно использовать для упаковки для проектируемых рыбных чипсов. Отличительной чертой данного изобретения является выполнение в виде пакетика из полимерного материала, имеющего дополнительную поверхность с крестообразным либо любой другой формы отверстием, при помощи которого упаковка надевается на горлышко бутылки [8].

Группой авторов Кутиной О.И., Могильным М.П., Шлёнской Т.В., Мираковым И.Р., Славянским А.А., Шаровой Т.Н. был разработан функциональный продукт на основе рыбного фарша. Технической задачей заявленного решения является повышение питательной ценности целевого продукта и повышение иммунного статуса у людей, а также усиления вкусовых качеств и органолептических показателей. Кроме того, расширение ассортимента диетических продуктов с функциональной направленностью, за счет подбора, сочетания и синергетического эфффекта компонентов. Разработанный продукт предназначен для профилактического и лечебного питания людей с целью улучшения иммунного статуса, обмена веществ, а также при профилактике онкологических заболеваний, после химиотерапии, укрепляя внутреннее сопротивление болезни [9].

Автором Ланиером Тэйр С. были предложены функциональные пищевые белковые ингредиенты из рыбы. Данная разработка касается фрракционирования (очистки) пищевых ингредиентов. Такие очищенные и/или измененные вещества составляют основную часть современного рынка пищевых ингредиентов, широкий ассортимент, который оценивается исключительно за их индивидуальные потребительские, функциональные свойства [10].

Авторами Saleena Mathew, Maya Raman, Manjusha Kalarikkathara, Parameswaran Dhanya, Pulikkottil Rajan представлена методика различных термических и нетермических методов обработки рыбы и рыбных продуктов. Также подробно рассматриваются различные рыбные продукты, подчеркивается важность показателей качества продукции [11].

Авторы Andrés-Bello A., García-Segovia P. \& Martínez-Monzó J. представляют передовые технологии по вакуумной жарке. Вакуумная жарка - это альтернативный способ улучшить качество жареной пищи и снизить окончательное поглощение масла продуктом. Продукт нагревается при низком давлении, что снижает температуру кипения масла для жарки и воды в продукте. Более того, отсутствие воздуха во время жарки в вакууме может препятствовать окислению липидов и ферментативному потемнению, следовательно, цвет и питательные вещества образцов могут быть в значительной степени сохранены. Данное исследование представляет обновленную информацию о последних достижениях в технологии вакуумной жарки, демонстрируя влияние предварительной обработки и условий жарки на качественные характеристики продуктов. Приведены факты, касающиеся оборудования и условий эксплуатации. С другой стороны, также упоминаются математические модели для описания поглощения масла и потери воды в процессе обработки. Также обсуждается влияние этой обработки на цвет, текстуру и пищевую ценность конечных продуктов [12].

Рапс - хороший источник высококачественного белка. Однако его использование как в пище для людей, так и в кормах для животных, ограничено наличием большого количества клетчатки и антипитательных факторов, таких как глюкозинолаты, полифенолы и фритиновая кислота (фитаты). Авторы Siy R.D. \& Talbot D.F. представили исследование по приготовлению низкофитатного белка рапсового семени путем ультрафильтрации: водная экстракция фритата из обезжиренного шрота из рапсового семени, экстракция фритатов, азотсодержащих, фоссфорсодержащих соединений из рапсового шрота и муки сортов Tower и Candle водным раствором хлорида натрия. Метод экстракции рассматривается как первый шаг в получении мембранного белка из семян рапса с низким содержанием фритата. В частности, данная разработка может быть использована как один из методов извлечения белка [13].

На основании полученной информации в качестве основного рыбного сырья для изготовления чипсов функциональной направленности была использована рыба ротанголовешка, богатая полиненасыщенными жирными кислотами (ПНЖК), филе рыбы со-

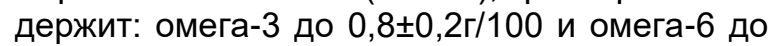
$0,6 \pm 0,06 r / 100$, незаменимые аминокислоты, минеральные вещества, витамины A, D, E. Данная продукция низкокалорийна и богата легкоусвояемыми белками, предназначена для повышения иммунитета и может применяться в диетическом питании, т.к. легко переваривается и усваивается. В таблице 1 представлен химический состав рыбы ротан. 
Таблица 1 - Химический состав рыбы ротан

Table 1 - Chemical composition of rotan fish

\begin{tabular}{|l|l|l|l|l|l|l|l|l|l|}
\hline Показатель & Б, г & Ж, г & PP, г & S, мг & Cr, мкг & F, мкг & Mo,кг & Ni, мкг & Zn, мг \\
\hline Рыба ротан & 17,5 & 2,1 & 2,9 & 175,0 & 55,0 & 430,1 & 4,0 & 6,6 & 30,7 \\
\hline
\end{tabular}

Данное сырье имеет большой потенциал к применению в качестве основного ингредиента для изготовления чипсов функциональной направленности, т.к. имеет приятный вкус, цвет, а также значительные запасы.
На рисунке 1 представлена технологическая схема изготовления чипсов функциональной направленности. Рецептура изготовления чипсов из рыбы функциональной направленности представлена в таблице 2.

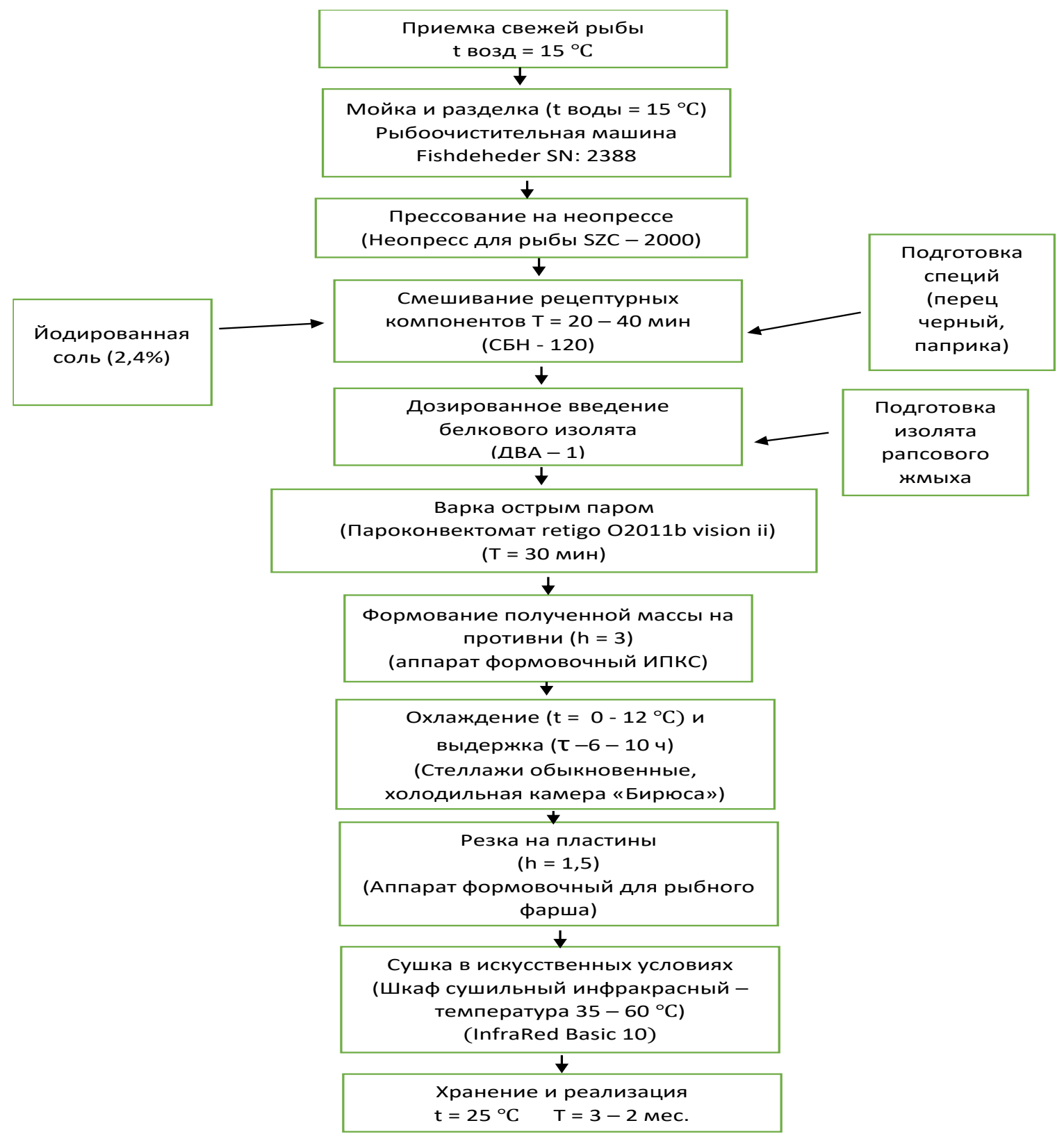

Рисунок 1 - Технологическая схема изготовления чипсов функциональной направленности

Figure 1 - Technological scheme for the production of functional chips 
Таблица 2 - Рецептура чипсов из рыбы функциональной направленности

Table 2 - Formulation for functional fish chips

\begin{tabular}{|c|c|c|}
\hline Наименование сырья & $\begin{array}{c}\text { Единица } \\
\text { измерения }\end{array}$ & г/100 \\
\hline Филе рыбы ротан-головешка & г & 72 \\
\hline Изолят белка рапсового жмыха & г & 24 \\
\hline Соль & г & 0,5 \\
\hline Перец черный & г & 0,5 \\
\hline Паприка & г & 1 \\
\hline Специи для рыбы & г & 2 \\
\hline
\end{tabular}

В результате технологического процесса содержание суммарного количества белка в готовой продукции увеличилось на $42,5 \%$ и составило 23,7 г/100, что больше $15 \%$ от суточной нормы потребления в одной порции готовой продукции с выходом 75 г.

Таким образом, разработана рецептура и технология производства чипсов из рыбы функциональной направленности с улучшенными органолептическими свойствами (вкус, запах), повышенной пищевой ценностью, гомогенным внешним видом, сокращением трудоемкости до $20 \%$, снижением энергозатрат на их приготовление до 14,0 \%, понижена себестоимость продукции на 12-13\%.

\section{ЗАКЛЮЧЕНИЕ}

Исходя из проведённого патентно-инфрормационного поиска, можно сделать вывод, что существует значительное количество результатов исследований по разработке рецептур и технологии производства продуктов функционального назначения на основе нетрадиционного рыбного сырья, обогащённого различными полифункциональными ингредиентами.

Актуальность исследования подтверждается формированием специализированных рационов питания С включением рыбы ротанголовешки для изготовления чипсов с повышенным содержанием белка в меню предприятий общественного питания для различных социальных групп, особенно проживающих в труднодоступных районах, а также для населения, выполняющего тяжёлые физические работы в экстремальных арктических территориях.

\section{СПИСОК ЛИТЕРАТУРЫ}

1. Попов В.Г. Теоретико-методологические подходы к разработке и практическому применению функциональных напитков для школьного питания: дис. ... д-ра техн. наук: 05.18.15 / В.Г. Попов ; Тюменский гос. нефтегазовый университет; КемТИПП. Кемерово : КемТИПП; 2014. 420 с. (в пер.)

2. Пат. № 2457696C1, RU, A23L 1/325, 2011106407/13, «Способ производства чипсов из прудовой рыбы». Авторы: Антипова Людмила Васильевна, Дворяни- нова Ольга Павловна, Калач Елена Владимировна. Патентообладатель : Государственное образовательное учреждение высшего профессионального образования "Воронежская государственная технологическая академия" (ГОУ ВПО ВГТА). Заявлено: 21.02.2011. Опубликовано: 10.08.2012. Бюл. № 22. С. 1-2.

3. Пат. № 2050796 C1, RU, A23L 1/325, «Способ производства рыбных и мидийных крекеров»; Авторы: Яковлева З.А. и Зубченко Д.Г. Патентообладатель: Южный научно-исследовательский институт морского рыбного хозяйства и океанографии (UA). Заявка: 5056590/13, 26.05.1992. Дата публикации: 27.12.1995.

4. Пат. № 2571791, RU, A23L 1/325, «Способ получения чипсов из Хамсы». Авторы: Артемов Р.В., Артемов А.В., Арнаутов М.В. Патентообладатель: Федеральное государственное бюджетное научное учреждение "Всероссийский научно-исследовательский институт рыбного хозяйства и океанографии" (ФГБНУ "ВНИРО"). Заявлено: 08.08.2014. Опубликовано: 20.12.2015. Бюл. № 35.

5. Пат. № 2295250 C2, RU, A23J 1/14, A23J 3/14, A23L 1/29, «Способ фрракционирования жмыха и измельченного жмыха масличных семян». Авторы: Стен Квист, Томми Карльссон, Джон Марк Лотер, Де Кастру Фернанду Басиле. Патентообладатель: «Биовелоп Интернешнл» (NL). Заявлено: 20.04.2005. Опубликовано: 20.03.2007. Бюл. № 8.

6. Пат. № 2437552 C1, RU, A23J 1/14, «Способ получения белка из жмыха семян льна». Авторы: Миневич И.Э., Осипова Л. Л., Зубцов В.А. Патентообладатель: Государственное научное учреждение «Всероссийский научно-исследовательский институт механизации льноводства Российской академии сельскохозяйственных наук» (ГНУ ВНИИМЛ Россельхозакадемии). Заявлено: 09.07.2010. Опубликовано: 27.12.2011. Бюл. № 36.

7. Пат. № 2277794 C1, RU, A23J 1/14, A23J 3/30 A23J 3/14 A23J 3/34 «Способ получения структурно модифицированного рапсового белкового продукта». Авторы: Лобанов В.Г., Минакова А.Д., Шульвинская И.В., Щербаков В.Г., Щербин В.В. Патентообладатель: Государственное образовательное учреждение высшего профессионального образования "Кубанский государственный технологический университет" (ГОУ ВПО "КубГТУ"). Заявлено: 27.12.2014. Опубликовано: 20.06.2006. Бюл. № 17.

8. Пат. № 67073 U1, RU, B63D 83/00, «Упаковка для сушеных пищевых продуктов». Авторы: Эльдарханова И.Б. и Эльдарханов Р.А. Патентообладатель: Эльдарханова Ирина Борисовна (RU). Заявлено: 06.03.2007. Опубликовано: 10.10.2007. Бюл. № 28.

9. Пат. № 2634117 C2, RU, A23L 17/00, «Функциональный продукт на основе рыбного фрарша». Авторы: Кутина О.И., Могильный М.П., Шлёнская Т.В., Мираков И.Р., Славянский А.А., Шарова Т.Н. Патентообладатель: Кутина Ольга Иосифовна (RU). Заявлено: 29.12.2015. Опубликовано: 05.07.2017. Бюл. № 19. 


\section{АКТУАЛЬНОСТЬ РАЗРАБОТКИ РЕЦЕПТУР И ТЕХНОЛОГИЙ ПРОИЗВОДСТВА РЫБОРАСТИТЕЛЬНЫХ ЧИПСОВ ИЗ НЕТРАДИЦИОННОГО РЫБНОГО СЫРЬЯ}

10. Lanier, T.C. (1994). Functional food protein ingredients from fish, in Seafood Proteins, Sikorski, Z.E., Pan, B.S., and Shahidi, F., Eds., Chapman Hall, New York, chap. 10.

11. Saleena Mathew, Maya Raman, Manjusha Kalarikkathara Parameswaran, Dhanya Pulikkottil Rajan. «Fish and Fishery Products: Quality Indices» // D.P. (2019). Fish and Fishery Products: Quality Indices. In: Fish and Fishery Products Analysis. Springer, Singapore. First Online: 07 November 2019. P. 1.

12. Andrés-Bello, A., García-Segovia, P. \& MartínezMonzó, J. «Vacuum Frying: An Alternative to Obtain HighQuality Dried Products» // Food Engineering Reviews 3, 63 (2011). Accepted: 13 May 2011. Published: 25 May 2011. P 1.

13. Siy, R.D. \& Talbot, D.F. «Preparation of low-phytate rapeseed protein by ultrafiltration: I. The aqueous extraction of phytate from deoiled rapeseed meals» // Journal of the American Oil Chemists' Society volume 59, pages 191-194 (1982). Received: 11 July 1980. Issue Date: April 1982.

\section{Информация об авторах}

C. В. Кузьмин - магистрант кафедры «Товароведения и технологии продуктов питания (профриль пищевая биотехнология)», ФГБОУ ВО «Тюменский Индустриальный Университет».

В. Г. Попов - д.m.н., профрессор, заведующий кафредрой товароведение и технология продуктов питания, ФГБОУ ВО «Тюменский Индустриальный Университет».

И. В. Мозжерина - доцент кафредры Товароведения и технологии продуктов питания ФГБОУ ВО «Тюменский Индустриальный Университет».

\section{REFERENCES}

1. Popov, V.G. (2014). Theoretical and methodological approaches to the development and practical application of functional drinks for school meals. Doctor's thesis.Kemerovo: KemTIPP. (In Russ.).

2. Antipova, L.V., Dvoryaninova, O.P. \& Kalach, E.V. (2012). Method for the production of chips from pond fish. Pat. 2457696C1. Russian Federation, published on 10.08.2012.Bul. 22. (In Russ).

3. Yakovleva, Z.A. and Zubchenko, D.G. (1995). Method for the production of fish and mussel crackers. Pat. 2050796 C1, Russian Federation, published on 12.07.1995. (In Russ).

4. Artemov, R.V., Artemov, A.V. \& Arnautov, M.V. (2015). Method for obtaining chips from Hamsa. Pat. 2571791. Russian Federation, published on 20.12.2015. Bul. 35. (In Russ).
5. Sten, Quist, Tommy, Karlsson, John Mark, Lother \& De Kastru, Fernando Basile. (2007). Method for fractionation of cake and crushed oilseed cake". Pat. 2295250 C2, RU. Published: 20.03.2007 Bul. 8. (In Russ).

6. Minevich, I.E., Osipova, L.L. \& Zubtsov, V.A. (2011). Method for producing protein from flax seed meal. Pat. 2437552 C1, RU. Published: 27.12.2011 Bul. 36. (In Russ).

7. Lobanov, V.G., Minakova, A.D., Shulvinskaya, I.V., Shcherbakov, V.G. \& Shcherbin, V.V. (2006). Method of obtaining a structurally modified rapeseed protein product. Pat. 2277794 C1, RU. Published: 20.06.2006 Bul. 17. (In Russ).

8. Eldarkhanova, I.B. and Eldarkhanov, R.A. (2007). Packaging for dried food.Pat. 67073 U1, RU, Published: 10.10.2007. Bul. 28. (In Russ).

9. Kutina, O.I., Mogilny, M.P., Shlyonskaya, T.V., Mirakov, I.R., Slavyansky, A.A. \& Sharova, T.N. (2015). Functional product based on minced fish. Pat. 2634117 C2, RU. Published: 07.05.2017. Bul. 19. (In Russ).

10. Lanier, T.C. (1994). Functional food protein ingredients from fish, in Seafood Proteins, Sikorski, Z.E., Pan, B.S. and Shahidi, F., Eds., Chapman Hall, New York, chap. 10

11. Saleena, Mathew, Maya, Raman, Manjusha, Kalarikkathara Parameswaran \& Dhanya Pulikkottil Rajan. (2019). Fish and Fishery Products: Quality Indices. Fish and Fishery Products: Quality Indices. In: Fish and Fishery Products Analysis. Springer, Singapore, (1), P. 1.

12. Andrés-Bello, A., García-Segovia, P. \& Martínez-Monzó, J. (2011). Vacuum Frying: An Alternative to Obtain High-Quality Dried Products.Food Engineering Reviews, 63 (3), P. 1.

13. Siy, R.D. \& Talbot, D.F. (1982). Preparation of low-phytate rapeseed protein by ultrafiltration: I. The aqueous extraction of phytate from deoiled rapeseed meals. Journal of the American Oil Chemists' Society volume,(59), 191-194.

\section{Information about the authors}

S. V. Kuzmin - magistrate of the Department of Commodity Science and Food Technology (profile food biotechnology), Tyumen Industrial University.

V. G. Popov - Doctor of Technical Sciences, Professor, Head of the Department of Commodity Science and Food Technology, Tyumen Industrial University.

l. V. Mozzherina - Associate Professor of the Department of Commodity Science and Food Technology, Tyumen Industrial University.

Авторы заявляют об отсутствии конфликта интересов.

The authors declare that there is no conflict of interest.

Статья поступила в редакцию 12.04.2021; одобрена после рецензирования 10.09.2021; принята к публикации 17.09.2021.

The article was received by the editorial board on 12 Apr21; approved after editing on 10 Sep 21; accepted for publication on 17 Sep 21. 